\title{
呼吸不全死した原発性肺高血圧症： 肺移植手術適応についての考察
}

$\begin{array}{lllll}\text { 中元 } & \text { 賢武, 前田 } \text { 昌純, 亀山耕太郎, 杉田 礼典 } \\ \text { 林 } & \text { 栄一, 岡田 } \text { 貴浩, 桂 } & \text { 浩, 坪田 典之 }\end{array}$

\section{要旨}

無症候期に胸部 $\mathrm{X}$ 線写真で発見され，6 年の経過で死亡した15歳の女性の原発性肺高血圧症の 1 例を 経験した．初回入院時の胸部X線写真では両側肺動脈の著しい抁張がみられ肺動脈平均圧は $60 \mathrm{mmHg}$ であった. 定期的な右心カテーテル検査では初期 3 年間は心係数，肺血管抵抗の改善がみられたが，そ の後, 右心不全が進行, 循環動態諸量も進行性に悪化し, 喀血, 呼吸不全で死亡した. 本症例は肺移植 適応患者と考えられ, retrospective に循環動態から推定移植時期その他の問題点について考察した.

索引用語：原発性肺高血圧症, 肺移植手術適応 primary pulmonary hypertension, potentiality of lung transplantation

\section{はじめに}

欧米に括ける肺移植の対象疾患は，移植成績 の向上とともに挔大してきた ${ }^{1}$. 従来, 心肺移植 の適応 ${ }^{2}$ と考光られた原発性, 2 次性肺高血圧 症にも片肺移植が応用されはじめた ${ }^{3-6)}$. 我々は 無症候期に発見し, 治療経過 6 年で呼吸不全死 した原発性肺高血圧症 (PPH) の 1 例を経験し た. 本症例を retrospective に検討し, $\mathrm{PPH} へ$ の肺移植適応に拈ける問題点につき考察した.

\section{症例}

症 例：15歳，女性.

主 訴: 縱隔腫瘤陰影

既往歴, 家族歴：特記事項なし. 月経正.

臨床経過：1983年11月, 感冒䍜患時の胸部X 線写真で縦隔腫瘍を疑われ当科を紹介され来院

香川医科大学 第二外科

原稿受付1993年 2 月 22 日

原稿採択1993年 8 月 2 日
した (Fig. 1). 初診時無症状で心聴診上, II 音 の无進を認めた. 心電図上，完全右脚ブロック， 右軸偏位, 左房拡大, 右室肥大を認めた. RI 血 管造影で腫瘤影は肺動脈の拡張と判明した

(Fig. 2). 肺機能検査で換気諸量は正常であっ たが，\%DLCO 68\%と軽度低下を認めた。深部 静脈血栓症は認めなかった. 右心カテーテル検 查では肺動脈平均圧 (PAP) は60 mm と と著 しく高く, 心内シャント, 弁膜疾患は認めず, 原発性肺高血圧症 (PPH) と診断した. 同時に 施行した PGE1，Hydrolazine による肺血管拡 張効果は認めなかった. 以後強心利尿剂による 治療を行なった，循環動態の経過をみるために 行なった1985年8月での右心カテーテル検査で は PAP は54 mmHg と軽度低下し, 心係数 (C. I.) は3.5 L/min $・ \mathrm{~m}^{2}$, 全肺血管抵抗 (TPVR)

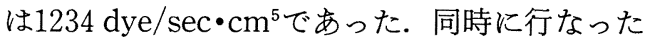
Diltiazem $0.15 \mathrm{mg} / \mathrm{kg}$ 静注で PAP は不変で あったが, C.I. は4 $1 \mathrm{~L} / \mathrm{min} ・ \mathrm{~m}^{2}$, 投与前より $16 \%$ 上昇し TPVR は1054 dyne $/ \mathrm{sec} \cdot \mathrm{cm}^{5}$ と投 与前より $15 \%$ 低下し有効であった. 以後強心利 


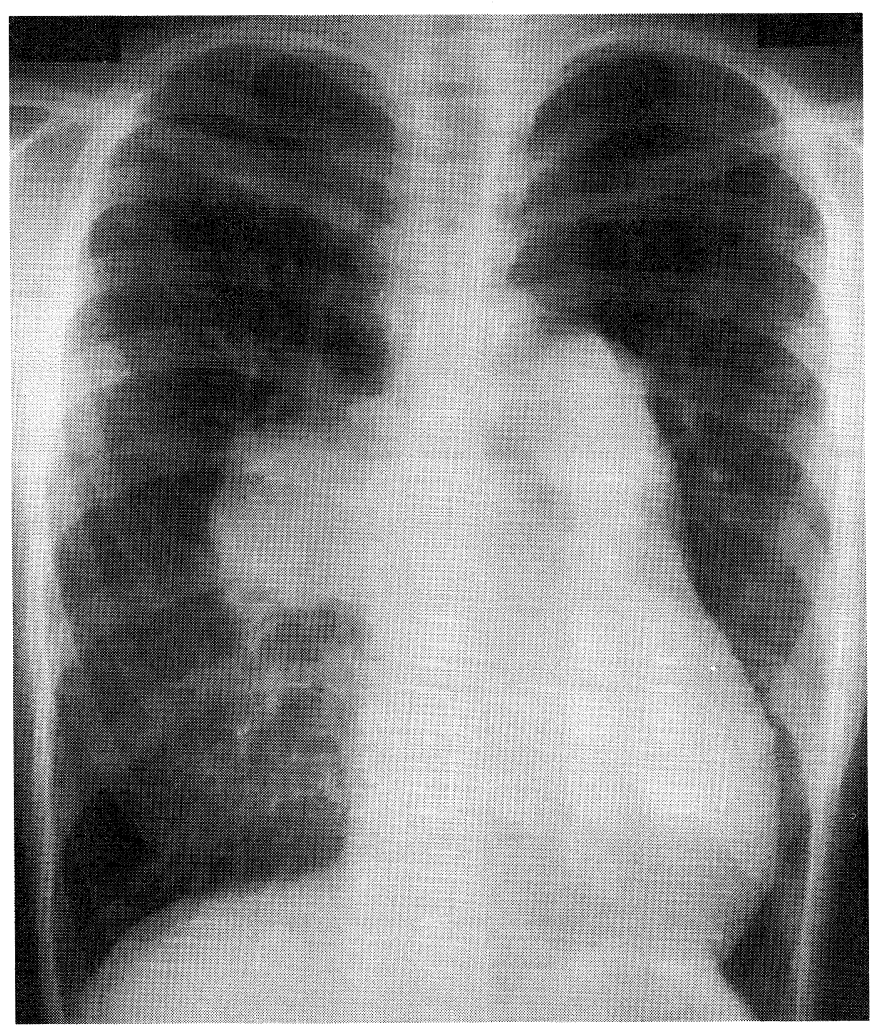

Fig. 1 Chest X-ray film on the first admission

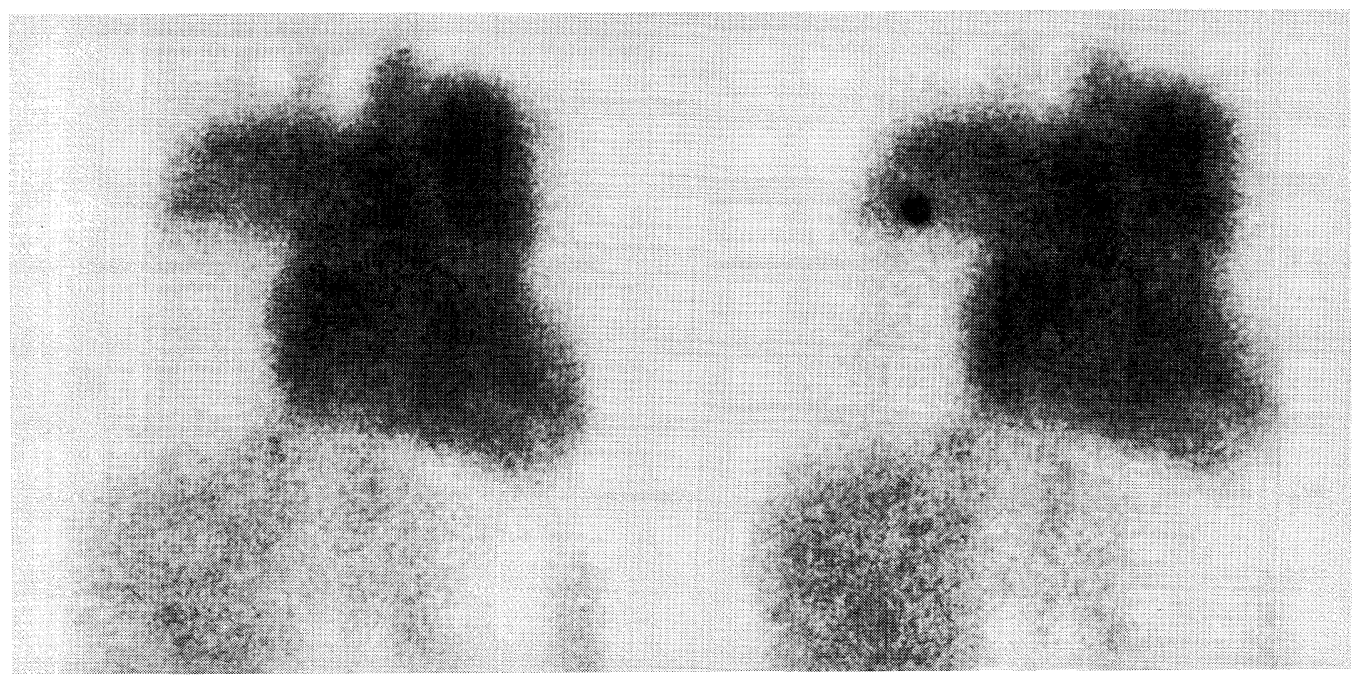

Fig. 2 RI angiogram during first hospitalization

尿剂と Ca 拮抗剤で治療を行なった. 1986年 4 月頃, 血痰が出現したが, NYHA では I 〜 II と 比較的安定していた. 1986年 8 月の右心カテー
テル検査では PAP は $58 \mathrm{mmHg}$ とやや上昇し ていたが, C.I. は $4.2 \mathrm{~L} / \mathrm{min} ・ \mathrm{~m}^{2}$, TPVR は1105 dyne/sec・cm5であった. 動脈血ガス分析では 


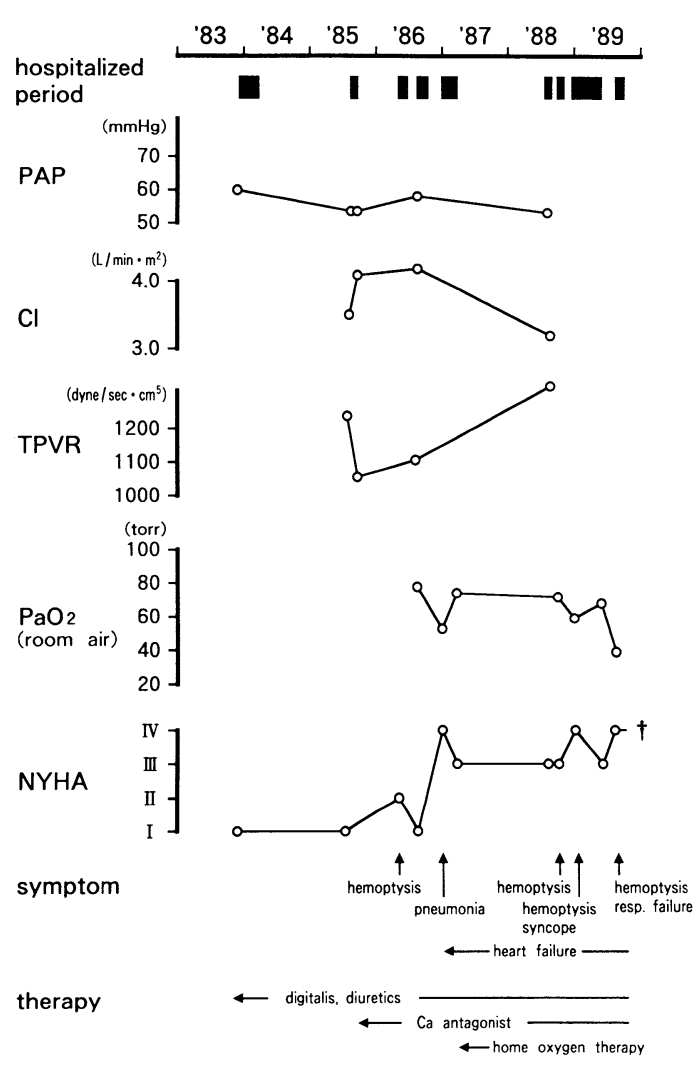

Fig. 3 Clinical course of primary pulmonary hypertension

$\mathrm{PaO}_{2}$ は78 torr と軽度低下していた. 1987年 1 月, 肺炎を併発し血痰, 右心不全, 呼吸困難出 現し緊急入院した. $\mathrm{PaO}_{2}$ は51.5 torr と著しく 低下していた．安静拉よび強心利尿剂にて右心 不全は改善し, $\mathrm{PaO}_{2}$ も74 torr に回復して退院 した．退院後 PAP 低下目的で在宅酸素療法を 開始した. 1988年 9 月第 4 回の右心カテーテル 検査では, PAP は53 mmHg と前回より $8.6 \%$ 低下していたが，C.I. も $3.2 \mathrm{~L} / \mathrm{min} ・ \mathrm{~m}^{2}$ と前回 より $30.0 \%$ の低下がみられた.この頃より心エ コーでは肺動脈弁および三尖弁閉鎖不全が認め られ，NYHA もIIIで，右心不全状態が続いた。 その後更に喀血, 失神も出現, 血液ガス分析で も $\mathrm{PaO}_{2}$ は次第に低下し, 入退院を繰り返した。 1989年 8 月, 大量喀血, 呼吸不全で緊急入院, 挿管補助換気を施行したが DIC も併発し, PPH 診断後 6 年の経過で死亡した (Fig. 3).

\section{考察}

原発性肺高血圧症は，原因不明の肺高血圧症 で, 50\%生存期間1.9年と極めて予後の悪い疾患 である7). 63\%は右心不全で死亡するが，その 他, 突然死, 肺炎で死亡する7). 治療は右心不全 の治療に加光, 種々の血管抎張剂療法 ${ }^{8)}$, 二次性 血栓予防のための抗凝固療法が行なわれてい る7). しかし, 病態が症例ごとに異なるため, そ の有効性は一様でなく, 予後への寄与も証明さ れていない，そのため欧米では進行例に扣いて， 根本治療として，心肺同時多植 (HLTX) がな されている2). 最近, Eisenmenger 症候群に樎 った心房中隔欠損症, あるいは肺動脈幹開存症 に対し，心奇型の修復と同時に片肺移植 (SLTX)の成功が報告され ${ }^{3,4}$, HLTX より手 術成績のよい $\mathrm{SLTX}^{9}$ が $\mathrm{PPH}$ へも適応されて きた ${ }^{4-6)}$. いずれの報告も SLTX で移植肺は血 流比で89 94\%を占め十分機能し, reperfusion pulmonary edema が極期となる $8 \sim 12$ 時間以 後, 循環諸量も早期に改善している. 右心機能 が可逆性であれば SLTX は HLTX にかわる PPH の根本的治療になることが示された.

本症例は 6 年の経過で死亡したが，その経過 中, SLTX の適応時期があったと考えられる. SLTX の recipient 選択基準9 ${ }^{9}$ ， 不可逆性進 行性の末期呼吸不全患者で余命 $1 \sim 1.5$ 年と予 測され, 右心不全 (三尖升閉鎖不全, 腹水, 肝 腫大，右室収縮力低下）のないことが条件とさ れている. 本症例にこの選択基準を照らすと, SLTX の施行時期は余命 $1 \sim 1.5$ 年となる PPH 診断後 4.5〜 5 年にあたる (Fig. 3). しか し, この時期はすでに右心不全症状を繰り返し ているため, 右心不全徵候のない時期である 1987年 1 月以前となる. 一方，早期診断，早期 治療開始で PPH の寛解する症例が，稀でない との報告がある ${ }^{10)}$. 本症例では PPH 診断後約 3 年間は PAP が高いものの血管拡張剂で心係 数 (C.I.), 肺血管抵抗 (TPVR) が改善傾向を 示し，この時期は寛解期にあたると考えられた。 しかし，それ以後は予後決定因子といわれるC. I., TPVR ${ }^{7,15)}$ の悪化がみられた. 治療効果が固 
定し初めて心不全に至った1987年 1 月が SLTX の決定時期であったと考光られる。一 方, 肺動脈 banding で作製した右心不全犬8), 慢性肺塞栓症での右心不全例 ${ }^{11)}$, SLTX を施行 した Eisenmenger 症候群では, 後負荷解除で右 室駆出率 (RVEF), 右室 1 回拍出量や, 三尖弁 閉鎖不全が改善し，右心不全の可逆性が示され ている4). 右心不全徵候が出現した後でも, コン トロール可能であれば1987年 1 月以降でも SLTX は可能とも考兄られる. 右心不全となっ た PPH での SLTX の可否は, 右心機能の可 逆性を示すより的確なパラメーター，抒よびそ の限界值の規定が今後必要と考光られる.

本症例でSLTX を想定するに打いて, 他の問 題は，術中に怙ける人工心肺の使用およびドナ 一肺との matching がある. 通常の SLTX や 両側 SLTX では, 人工心肺を必要としない例も あるが，右心不全に陥りはじめた PPH では肺 血管が器質的変化を扣こし硬管となっている可 能性が高く, 人工心肺は必須と考えられる.心 内操作が不要であるため部分体外循環で対処可 能である. 近年, 経皮的送脱血システム (PCPS) が導入され, 比較的簡便, 迅速な体外循環が可 能となっている ${ }^{12)}$. 右肺癌全摘後の対側転移の 再手術，気管分岐部直上の腫痬性狭窄に対する 分岐部へのアプローチに PCPS を応用した経 験がある. SLTX での術中心不全, 低酸素症に 陥る症例に応用可能と考光る.

本症例では肺動脈が著明に拡大しているため, 移植時ドナー肺動脈との matching が問題とな りらる. 肺動脈口径差の修正には，ドナー肺動 脈を本幹でトリミングしカフを付けた状態での 吻合9が考えられる.

潜在的肺移植適応患者之考号られた $\mathrm{PPH}$ の 一例を経験し, 移植を想定した場合の問題点を retrospective に考察した.

\section{文献}

1) 日胸外会藏器移植問題特別委員会編：心蔵移
植, 肺移植一一技術評価と生命倫理に関する総 括レポート第 2 版，金芳堂，京都，1992.

2) Reitz BA, Wallwork JL, Hunt SA, et al : Heart-Lung transplantation. Successful therapy for patients with pulmonary vascular disease. N EngI J Med 306 : 557-564, 1982.

3) Fremes SE, Patterson GA, Williams WG, et al : Single lung transplantation and closure of patent ductus arteriosus for Eisenmenger's syndrome. J Thorac Cardiovasc Surg 100 : 1 $-5,1990$.

4) McCarthy PM, Rosenkranz ER, While RD, et al: Single-lung transplantation with atrial septal defect repair for Eisenmenger's syndrome. Ann Thorac Surg 52 : 300-303, 1991.

5) Calhoon JH, Grover FL, Gibbons WJ, et al : Single lung transplantation. Alternative indications and technique. J Thorac Cardiovasc Surg 101: 816-825, 1991.

6) Pasque MK, Kaiser LR, Dresler CM, et al : Single lung transplantation for pulmonary hypertension. Technical aspects and immediate hemodynamic results. J Thorac Cardiovasc Surg 103: 475-482, 1992.

7) Fluster V, Steele PM, Edwards WD, et al : Primary pulmonary hypertension; Natural history and the importance of thrombosis. Circulation 70:580-587, 1991.

8) Weir EK, Rubin LJ, Ayres SM, et al: The acute administration of vasodilators in primary pulmonary hypertension. Experience from the National Institutes of Health Registry on primary pulmonary hypertension. Am Rev Respir Dis 140 : 1623-1630, 1989.

9) Egan TM, Kaiser LR, Cooper JD: Lung transplantation. Curr Probl Surg 26:673752, 1989.

10) Rozkovec A, Montanes P, Moakley CM : Factors that infiuence the outcome of primary pulmonary hypertension. Br Heart J 55 : 449-458, 1986.

11) Daily PO, Dembitsky WP, Peterson KL, et al: Modifications of techniques and early results of pulmonary thromboendarterectomy for chronic pulmonary embolism. J Thorac Cardiovasc Surg 93 : 221-233, 1987.

12) 正井崇史, 松田 暉, 中埜 肃, 他：一時的心 肺補助のための大腿動静脈アプローチによる 閉鎖式 cardiopulmonary bypass system の関 発とその臨床的応用例. 人工蔵器 $19: 182-185$, 1990. 


\section{Retrospective evaluation of possible lung transplantation for primary pulmonary hypertension}

Kembu Nakamoto, Masazumi Maeda, Kohtaro Kameyama, Ayanori Sugita, Eiichi Hayashi
Takahiro Okada, Hiroshi Katsura, Noriyuki Tsubota Second Department of Surgery, Kagawa Medical School, Kagawa, Japan

We treated a 15-year-old famale with primary pulmonary hypertension while she was still asymptomatic. After 6 years she died of respiratory failure. Her pulronary hemodynamics monitered by cardiac catheterization showed good response to medical therapy without any symptoms for the first 3 years, but then deterionated, and she suffered repeated hemoptysis, syncope, and heart failure during her last 3 years. The possible effectiveness of lung transplantation for this patient is disccussed retrospectively. 